\title{
James Taylor (1859-1946): favourite disciple of Hughlings Jackson and William Gowers
}

\author{
MJ Eadie \\ Emeritus Professor of Clinical Neurology and Neuropharmacology, Faculty of Health Sciences, University of Queensland, Royal Brisbane and \\ Women's Hospital, Brisbane, Australia
}

\begin{abstract}
In neurological circles today the name James Taylor (1859-1946) is probably remembered mainly for his role in editing the Selected Writings of John Hughlings Jackson, the most readily available source of Jackson's contributions to neurological knowledge. Taylors' own neurological achievements are largely or entirely forgotten, but in his day he was an influential figure whose career linked the great figures of the golden era of late nineteenth century British neurology to the neurology of the first half of the twentieth century. Not only was he a junior professional colleague and close friend of both John Hughlings Jackson and William Gowers, he also produced a substantial corpus of neurological writings in his own right, including a textbook of child neurology and the first English language account of subacute combined degeneration of the spinal cord.
\end{abstract} Correspondence to MJ Eadie, 'F' floor, Block 7 Royal Brisbane and Women's Hospital

Brisbane, Australia, 4029

tel. +6I $7383 I I 704$

e-mail M.Eadie@uq.edu.au

KEYWORDS Child neurology, Gowers, Hughlings Jackson, James Taylor,

Queen Square

DECLARATIONS OF INTERESTS No conflicts of interest declared.

\section{INTRODUCTION}

Almost 60 years ago, in his history of the National Hospital, Queen Square, London, Gordon Holmes provided brief biographical details of former members of the consultant staff.' In his account he described James Taylor as the 'favourite disciple and intimate friend of Hughlings Jackson and Gowers', the two greatest figures of the golden era of British clinical neurology, the later years of the nineteenth century. Yet today, if Taylor's name is remembered at all, it would probably be mainly by those interested in neurological history and he would be recognised mainly as the editor of the Selected Writings of John Hughlings Jackson. ${ }^{2}$ But was Taylor's discipleship of and friendship with the two great pillars of Victorian British neurology all there was to his professional life? Was there more to him than merely being devoted to greater men and serving as an instrument for the perpetuation of the memory of one of them?

\section{JAMES TAYLOR'S LIFE AND CAREER}

Before attempting to deal with these questions, it is useful to review Taylor's life and professional career, ${ }^{3-7}$ James Taylor (Figure I) was born at Forres, Morayshire, Scotland on 17 March 1859. He was the second son, and third of the eight children of Peter Taylor and his wife Eliza, née Lang. After attending Forres Academy, Taylor embarked on a career in banking before becoming a student at the University of Edinburgh. He gained a MA degree in natural sciences (in 1883) before commencing medical studies from which he graduated $M B, C M$, in

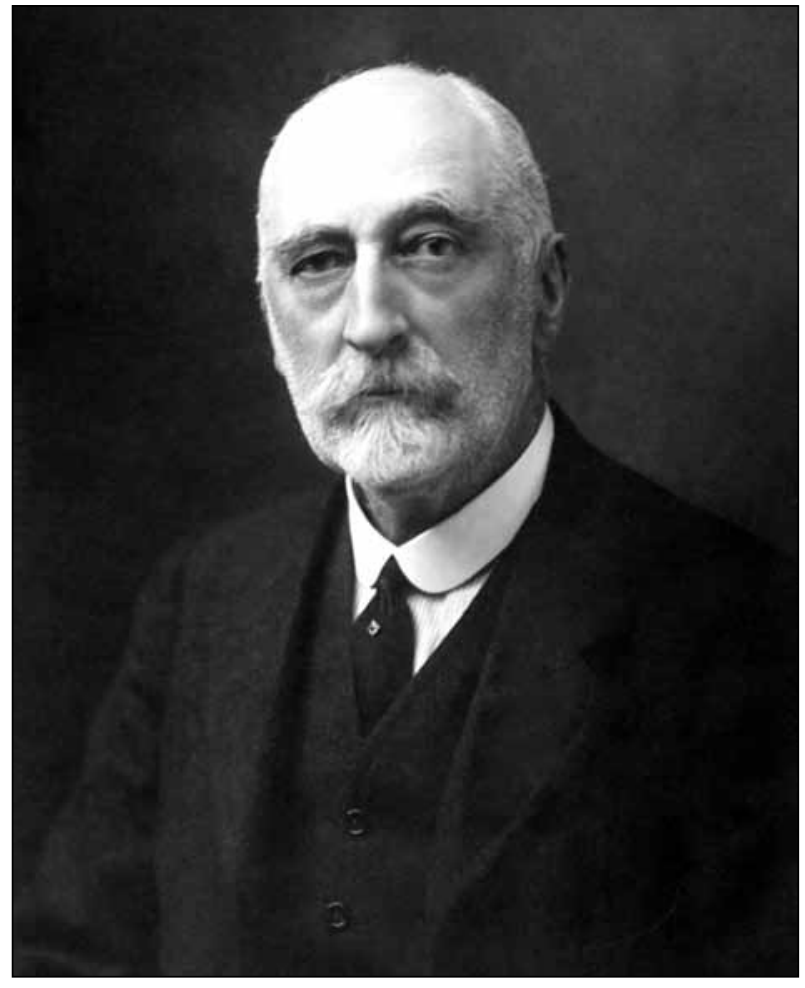

FIGURE I James Taylor (I859-1946). Courtesy of the Queen Square Library,Archive and Museum. Copyright National Hospital for Neurology and Neurosurgery.

1886. He then worked as a house physician in Edinburgh's Royal Infirmary and Hospital for Sick Children before undertaking postgraduate studies in Germany. On his return to Britain he took up an appointment as house 
physician at the National Hospital for the Paralysed and Epileptic, Queen Square, London in I889. In the following year he received his Edinburgh MD, and took the MRCP (London). Seven years later he became a Fellow of the London College. Taylor spent the remaining years of his professional career involved in the activities of the institution at Queen Square. By 189/ he had become registrar and pathologist to the hospital and, three years later, assistant physician. By 1897 he was senior assistant physician and in due course became outpatient physician, full physician and, by 1921, senior physician. On retirement from active duty in 1924, aged 65, he was appointed consultant physician to the Hospital. In his book on the history of the hospital Holmes described Taylor as 'a careful, painstaking physician and a lucid teacher' whose earlier commercial experience probably contributed to his ability to provide valued advice on the management of the Queen Square institution.'

For many years from 1899 onwards, Taylor also held consultant appointments to the Royal London Ophthalmic Hospital at Moorfields and to the Queen's Hospital for Children. During the First World War, he provided consultant services to the Osborne House Convalescent Home for Officers. His services in that war were followed by the award of a CBE in 1920. His attainments in the field of neurology were acknowledged with the presidency of the Neurological Section of the Royal Society of Medicine in 1915, and of its Section of Ophthalmology in 1920. He was also President of the Harveian Society of London in 1919.

Taylor married relatively late, aged 46, at Litcham in Norfolk, on II September 1905. His bride was Elizabeth Marian Cooke (1872-1956), whom he had met at Moorfields. The couple's only child was a daughter, Susan Euphemia Taylor (1909-2002).

Taylor's career progression suggests that he had been a successful but perhaps not particularly outstanding London consultant; one however held in professional respect by his peers. Had there not been more to his experience, his would seem to have been the sort of medical career that ensured a measure of contemporary admiration and respect that would not have long outlasted the duration of his professional activities.

\section{TAYLOR AND JOHN HUGHLINGS JACKSON}

When James Taylor first took up his appointment at Queen Square in 1889, John Hughlings Jackson (1835191I) and William Gowers (1845-1915) were already well established at that hospital and had become notable figures in the emerging specialty of clinical neurology. Taylor continued to hold appointments at Queen Square throughout the remainder of the careers of the two older men.
As early as 1892 Taylor's name appeared as co-author with Jackson in the report of a patient with double hemiplegia with bulbar symptoms, ${ }^{8}$ and two and three years later in reports of the return of the knee jerks following an attack of hemiplegia in a patient with tabes. ${ }^{9}, 10$ Whether these co-authored publications represent more than kindness on Jackson's part in attempting to get a younger man's publishing career underway, or whether Jackson had found something congenial or particularly worthy of nurture in Taylor, is unclear. However, throughout his career Jackson rarely published in collaboration with others. Evidence of Taylor's regard towards Jackson and his intellectual attainments is provided by his editing the re-publication in 1925, 14 years after Jackson's death, of a number of Jackson's papers in a volume entitled Neurological Fragments." Taylor included within that volume his own recollections of Jackson, ${ }^{12}$ and also those of Jackson's colleagues and friends Sir Jonathan Hutchinson and Charles Mercier. Subsequently, in 193I, the Guarantors of the journal Brain undertook responsibility for having Selected Writings of John Hughlings Jackson published in two volumes. ${ }^{2}$ Taylor edited the work with the assistance of two men who became great figures in British neurology in the first half of the twentieth century, Gordon Holmes and Francis Walshe. Since publication, these volumes have provided the main source of access to Jackson's ideas, partly because Taylor's editing organised the material in what was in retrospect a more logical order than in the original versions. Further evidence of Taylor's intent to memorialise Jackson was his involvement in arranging for a bust of Jackson to be placed in the National Hospital at Queen Square. Moreover, it was Taylor who authored the account of Jackson's life in the Dictionary of National Biography. ${ }^{13}$ On one occasion he also wrote on Jackson's wit. ${ }^{14}$

Other indications of the friendship that existed between these men can be found in the recorded statements of those who, in their professional youth, knew people in the generation that had itself known Jackson (Holmes [quoted above]' and Purdon Martin ${ }^{15}$ for example). Taylor himself wrote of how, when he had first moved into his own home, Jackson appeared bringing a sofa which he insisted Taylor would need. Later, after Taylor had married, Jackson unexpectedly arrived with a set of fish knives which he said had been a wedding gift that he, by then a rather reclusive widower, no longer needed and would like Taylor and his wife to have. ${ }^{2}$ The Critchleys, in their biography of Jackson, ${ }^{16}$ described how Jackson felt that he could arrive at Taylor's consulting rooms unheralded and immediately summon Taylor from the consultation that was in progress, and that Taylor did not seem to mind. When Jackson was away on vacations, Taylor attended to Jackson's correspondence, and kept in daily touch with him by telegraph. In his will, the long widowed and childless Jackson left Taylor a legacy of 
$£ 500$, but he did not make him his literary executor. Perhaps this was out of kindness towards Taylor, for Jackson directed that all of his papers should be destroyed after his death. He may have realised that requiring Taylor to do that would confront him with the dilemma of having to choose between denying himself (and posterity) access to what Taylor probably would have regarded as potentially invaluable documents, and failing to keep an obligation to a friend.

\section{TAYLOR AND WILLIAM GOWERS}

Taylor provided the index for the second edition of Gowers' Manual of Diseases of the Nervous System, ${ }^{17}$ and co-edited the first volume of the third edition of the Manual $^{18}$ with Gowers. Taylor's contribution to that volume cannot easily be identified, however. The second volume of the third edition never appeared in print, and the draft material for it, which has again come to light recently, contained alterations made in Gowers' handwriting only. ${ }^{19}$ Although Macdonald Critchley had access to this material in 1949 it is not known how he obtained it, though a possible source might have been Taylor or Taylor's family. Taylor's intended role in the proposed second volume therefore remains unknown. That Gowers involved Taylor in the production of the later editions of his seminal work, and that Taylor was willing to be involved at a stage where he was probably already busy professionally, gives some indication of the respect in which these two men probably held each other. It seems that there was also friendship between them, for Gowers, a talented amateur artist, gave the Taylor family at least one of his etchings. Critchley subsequently published an illustration of this etching in his biography of Gowers. ${ }^{20}$ Further, it was Taylor who signed Gowers' death certificate. ${ }^{21}$

It seems therefore that Taylor was not only the devoted disciple of these two greatest figures in the history of English clinical neurology but was also their close and trusted friend, and one who took what action he could to preserve the memory of Jackson in particular, who did not leave behind him a collection of writings that would have ensured a more lasting literary legacy.

Was Taylor responsible for any additional original or otherwise significant medical achievements, beyond his work with Jackson and Gowers?

\section{TAYLOR'S PUBLISHED WORK}

Beyond his work with Jackson and Gowers, James Taylor had a very substantial record of publication in the scientific literature of his time. It was probably considerably more extensive than that of most contemporary London physicians. His most substantial work was a 500 page monograph published in 1905,
Paralysis and Other Diseases of the Nervous System in Childhood and Early Life. ${ }^{22}$ Taylor stated in his preface that he had chosen to omit from his book literature references. Nevertheless he produced what was in effect a readable, competent and balanced account of the contemporary knowledge of many aspects of the neurology of childhood. His name was also listed among the authors of chapters in the second edition (19II) of Allbutt and Rolleston's System of Medicine. He wrote on occlusion of the cerebral vessels and the paralyses of childhood. ${ }^{23,24}$

A quite appreciable number of Taylor's journal publications first appeared in various medical society proceedings. Most of these papers comprise simple, brief reports of the features of single, or small numbers of interesting cases. Usually little or no associated discussion was included, though it seems likely this took place at the time and that Taylor would have contributed. The case material reported in these publications covered a wide variety of neurological conditions, e.g. acute myelitis, encephalitis lethargica, athetoid movements, trigeminal neuralgia, Friedreich's ataxia, myopathy, peroneal atrophy, but none probably had any enduring scientific significance.

Early in his career Taylor co-authored several papers concerned with the treatment of neurological disorders and later in life he indicated that he had always been interested in the treatment of epilepsy. He wrote a paper with Coleman which described the use of hyoscine as a sedative; ${ }^{25}$ a paper he wrote with Risien Russell, his fellow contemporary Edinburgh medical graduate, described the use of biborate of soda in treating epilepsy; ${ }^{26}$ he also wrote three more papers with this colleague on the treatment of tabes and other neurological disorders by means of suspension, a technique that Charcot had recently introduced (at a time when cervical spondylosis was unknown). The reported outcomes of the method seem rather equivocal and leave an impression that the treatment was useless - it soon disappeared from use. ${ }^{27-29}$

In 1895, Taylor wrote his first paper as sole author, providing the first English language account of subacute combined degeneration of the spinal cord, ${ }^{20}$ an entity that had been first described in 1887 by Lichtheim. ${ }^{30}$ Taylor recorded the clinical features of two cases and the findings at autopsy. Unfortunately, he didn't mention the appearance of the nerve roots or peripheral nerves or of the microscopic appearances of the peripheral blood (though one of the cases had a haemoglobin level of only $20 \%$ ). If the appearances of the red blood cells had been reported there probably would have been evidence of pernicious anaemia, and that would have reinforced the diagnosis. Taylor thought that the disorder might result from a toxic blood state with a haemorrhagic 
tendency. He questioned its relationship to what Gowers had described as 'ataxic paraplegia' (a now forgotten entity whose real nature has never been satisfactorily resolved). Taylor returned to the topic of 'subacute combined sclerosis' nine years later, ${ }^{31}$ describing a further case and providing a major review of the topic in which he suggested that Gowers 'ataxic paraplegia' was simply a stage in the evolution of subacute combined degeneration. Taylor's contemporaries and immediate successors seem to have regarded this work on subacute combined degeneration as his main contribution to medical knowledge.

Taylor was also early into print in several other emerging areas of clinical neurological knowledge. In 1897, he and Edward Semple described three instances of what they considered a spinal cord affection that had occurred in bicycle riders. ${ }^{32}$ Two of these cases seem likely to have been pressure palsies involving the innervation of the perineum due to the shape of the bicycle saddle, but the other was probably an instance of genuine spinal cord disorder, possibly multiple sclerosis. Taylor and his co-author recognised the local nerve pressure effects, but speculated that these effects resulted in spinal cord alterations. They had no autopsy material to support their interpretation.

In 1905 Taylor described two cases of myasthenia gravis, which had only recently been recognised as a disease entity, and suggested that the disorder was due to a toxin which affected the terminal axon. ${ }^{33}$ This concept could be regarded as a forerunner to the current concept of autoantibodies affecting the nicotinic acetylcholine receptor or, less often, other molecules in the region of the myoneural junction. However Campbell and Bramwell had made the same suggestion in 1901. ${ }^{34}$

Taylor's interest in neuro-ophthalmology was reflected in his writing on the distinction between optic neuritis due to tabes and due to disseminated sclerosis ${ }^{35}$ and on the occurrence of pituitary fossa enlargement associated with Leber's optic atrophy. ${ }^{36} \mathrm{He}$ collaborated with neurosurgeons, writing with Horsley on the operative treatment of tic douloureux ${ }^{37}$ and in 1903 with Ballance on the consequences of a subarachnoid blood cyst. ${ }^{38} \mathrm{On}$ two occasions he investigated syringomyelia. ${ }^{39,40}$ Later in his career he discussed epilepsy as a symptom rather than a disease in its own right, ${ }^{41}$ thus moving beyond the interpretation that his mentor, Gowers, had reached towards the end of his own career. Taylor was also interested in the relationship between chickenpox and herpes zoster ${ }^{42}$ and returned to this topic in a letter to the British Medical Journal written in the penultimate year of his long life. ${ }^{43}$

James Taylor's career indicates that he was a faithful and loyal disciple of the two great masters of late nineteenth century British neurology, John Hughlings Jackson and William Gowers, as well as their friend. Taylor's career linked the golden age of English language clinical neurology in the latter part of the Victorian era to the neurology of the first half of the twentieth century. His efforts to preserve the memory of Jackson's insights and achievements probably distracted attention from his own achievements in the development of clinical neurology, which are worthy of attention. Taylor came close on several occasions to identifying developments that were both original and important. However the neurological generation before him, including not only Jackson and Gowers but other notable Queen Square figures such as Ferrier and Bastian, and others on the continent, had already achieved many of the discoveries that could be made at the time by clinical observation and subsequent interpretation. Consequently the possibilities of further discoveries that remained open to Taylor and his contemporaries were somewhat limited until new basic knowledge and additional investigational methods became available. Taylor's interests and publications, ranging widely as they did over the field of neurological disorder, may have diluted the impact of his early textbook on child neurology. Had he not been involved in such a varied range of subjects, his name might be better remembered, simply as a pioneer child neurologist. 


\section{REFERENCES}

I Holmes G. The National Hospital Queen Square 1860-1948. Edinburgh: E \& S Livingstone; 1954.

2 Taylor JE (ed). Selected writings of John Hughlings Jackson. vol I and 2. London: Hodder \& Stoughton; 1931.

3 James Taylor MD FRCP. Br Med J 1946; 2:67-8.

4 Dr J Taylor, an eminent neurologist. The Times. London: 7 June 1946.

5 James Taylor CBE, MD, FRCP. Br J Ophthalmol 1946; 30:497-8.

6 James Taylor CBE, MA, MD Edin, FRCP. Lancet 1946; 247: 945.

7 Brown GH. James Taylor CBE. Lives of the Fellows of the Royal College of Physicians of London 1826-1925. London: Royal College of Physicians; 1955. p. 398.

8 Jackson JH, Taylor J. A case of double hemiplegia with bulbar symptoms. Lancet 1892; 140:1320-2. http://dx.doi.org/I0.1016/ SOI40-6736(0I)88279-9

9 Hughlings Jackson J, Taylor J. Remarks on a case of return of knee jerks after hemiplegia in a tabetic. Br Med J I89I; 2:57. http:// dx.doi.org/l0.1 136/bmj.2.1593.57

10 Hughlings Jackson J, Taylor J. A further note on the return of the knee jerk in a tabetic patient after an attack of hemiplegia. $\mathrm{Br}$ Med J 1894; I:I350. http://dx.doi.org/ I0.I I36/bmj. I.I747.1350

I I Taylor J, ed. Neurological fragments. By J Hughlings Jackson M.D., F.R.S. F.R.C.P. With a biographical memoir by James Taylor, M.D., F.R.C.P. London: Oxford Medical Publications; 1925.

12 Taylor J, ed. Biographical memoir. Neurological fragments. By Hughlings Jackson M.D., F.R.S. F.R.C.P. With a biographical memoir by James Taylor, M.D., F.R.C.P. London: Oxford Medical Publications; 1925. pp I-26

I3 Taylor J (revised Walton of Detchant). Jackson, John Hughlings (I835-191I). Oxford Dictionary of National Biography. Oxford: Oxford University Press; 2004

14 Taylor J. The wit of Hughlings Jackson. Lancet 1935; 225:963-4. http://dx.doi.org/I0.I0I6/S0I40-6736(0I)29545-2

15 Martin JP. Recollections of Queen Square. $\mathrm{Br}$ Med J 1981; 283:I640-2. http://dx.doi.org/I0.I I36/bmj.283.6307.1640

16 Critchley M, Critchley EA. John Hughlings Jackson. Father of English neurology. Oxford: Oxford University Press; 1998.

17 Gowers WR. A manual of diseases of the nervous system. 2nd ed. London: J \& A Churchill; 1893.

18 Gowers WR, Taylor J.A manual of diseases of the nervous system. 3rd ed. London: Churchill; 1899.

19 Eadie MJ, Scott AE, Lees A et al. William Gowers: the never completed third edition of the 'Bible' of neurology. Brain 2012; 135:3 1 78-88. http://dx.doi.org//0.1093/brain/aws I8I

20 Critchley M. Sir William Gowers 1845-19/5. A biographical appreciation. London: Heinemann; 1949.

20 Taylor J. On nervous symptoms and morbid changes in the spinal cord in certain cases of profound anaemia. Med Chir Trans 1895; 78: I5I-70.

21 Scott A, Eadie M, Lees A. William Richard Gowers 1845-1915. Exploring the Victorian brain. Oxford: Oxford University Press; 2012. http://dx.doi.org/10.1093/med/9780199692316.001.000I

22 Taylor J.Paralysis and other diseases of the nervous system in childhood and early life. London:J \& A Churchill; 1905.

23 Taylor J. Occlusion of the cerebral vessels. In: Allbutt C, Rolleston HD, eds. A system of medicine. 2nd ed (vol 8). London: Macmillan \& Co; 1911. pp. 290-306
24 Taylor J. Cerebral palsies of childhood. In:Allbutt C, Rolleston HD, eds. A system of medicine. 2nd ed (vol 8). London: Macmillan \& Co; I91 I. pp. 452-67.

25 Colman WS, Taylor J. Some notes on the value of hyoscine as a sedative. Lancet I889; I35:736-7. http://dx.doi.org/I0.1016/S0|406736(02)29908-0

26 Risien Russell JS, Taylor J.The treatment of epilepsy by biborate of soda. Lancet 1890; 135:106I-3. http://dx.doi.org/I0.1016/S0I406736(02) I8585-0

27 Risien Russell JS, Taylor J. Notes on some cases treated by suspension at the National Hospital for the Paralysed and Epileptic, Queen Square. Lancet I889; 134:785-7. http://dx.doi.org/I0.1016/ SOI40-6736(02)10820-8

28 Risien Russell JS, Taylor J. A second series of cases treated by suspension at the National Hospital for the Paralysed and Epileptic, Queen Square. Lancet 1890; 135:234-5. http://dx.doi.org//0.1016/ SOI40-6736(02) I460I-0

29 Risien Russell JS, Taylor J. Treatment by suspension. Brain 1890; 1 3:206-23. http://dx.doi.org// 0.1093/brain//3.2.206

30 Lichtheim L. Zur Kenntnis der perniziösen Anämie. Schweiz. Med Wochenscht 1887; 34:300. German.

31 Taylor J. A case of "subacute combined sclerosis" with profound anaemia. Brain 1904; 27:27-37. http://dx.doi.org/I0.1093/brain/27.I.27

32 Semple E, Taylor J. On certain symptoms of spinal cord affection in bicycle riders. Lancet 1897; |49:1084-5. http://dx.doi.org//0.1016/ SOI40-6736(0I)94727-0

33 Taylor J. A clinical lecture on myasthenia gravis. Br Med J 1905; I:5 I7. http://dx.doi.org/I0.I I36/bmj.I.2306.5I7

34 Campbell H, Bramwell E. Myasthenia gravis. Brain 1900; 23:277336. http://dx.doi.org//0.1093/brain/23.2.277

35 Taylor J. Some neurological aspects of ophthalmic cases. Proc Roy Soc Med 1921; I4:1-7.

36 Taylor J. Changes in the sella turcica in family optic atrophy. $\mathrm{Br} \mathrm{J}$ Ophthalmol 1919: 3:193-7 http://dx.doi.org/10.1 I36/bjo.3.5.193

37 Horsley V, Taylor J, Colman WS. Remarks on the various surgical procedures devised for the relief or cure of trigeminal neuralgia (tic douloureux). Br Med J 1891;2: I I39-I |43; II91-I 193; I249-1252.

38 Taylor J, Ballance CA. A case of a large blood cyst in the arachnoid space simulating brain tumour; operation; recovery. Lancet 1903; 162:597-9. http://dx.doi.org//0.1016/S0 I40-6736(01)5056I-9

39 Taylor J. Case of syringomyelia, with necropsy. Lancet 1893; |4I:/86-90. http://dx.doi.org//0.1016/S0 |40-6736(00)803 I7-7

40 Taylor J, Greenfield JG, Martin JP. Two cases of syringomyelia and syringobulbia, observed clinically over many years, and examined pathologically. Brain 1922; 45:323-56. http://dx.doi.org//0.1093/ brain/45.3-4.323

4I Taylor J. A clinical lecture on epilepsy considered as a symptom not as a disease. Br Med J I92I; I:4. http://dx.doi.org//0.II36/ bmj.I.3I3I.4

42 Taylor J. Immunity following herpes. Br Med J 1928; I:920. http:// dx.doi.org/I0.1 I36/bmj.I.35I6.920

43 Taylor J. Herpes zoster and chicken pox. Br Med J 1945; 2:385. http://dx.doi.org//0.I I36/bmj.2.4420.385 